\title{
Effects of dietary soybean and sunflower oils with and without L-carnitine supplementation on growth performance and blood biochemical parameters of broiler chicks
}

\author{
S. M. A. Jalali, R. Rabiei, and F. Kheiri \\ Department of Animal Sciences, Faculty of Agriculture, Islamic Azad University, Shahrekord Branch, \\ Shahrekord, Iran \\ Correspondence to: S. M. A. Jalali (nutritionist.poultry@gmail.com)
}

Received: 10 July 2015 - Revised: 8 September 2015 - Accepted: 29 September 2015 - Published: 26 October 2015

\begin{abstract}
An experiment was designed to investigate the effects of soybean, sunflower oil and dietary Lcarnitine supplementation on growth performance, some blood biochemical parameters and antibody titer against Newcastle disease of broiler chicks. A 5-week feeding trial, 240 1-day old male broiler chicks (Ross 308) were randomly allocated to six dietary treatments as a $3 \times 2$ factorial experimental design where three sources of dietary oil contained soybean, sunflower and soybean plus sunflower oil with and without $120 \mathrm{mg} \mathrm{kg}^{-1}$ of Lcarnitine supplementation in the diet. Results showed that soybean oil with L-carnitine significantly improved body weight gain and feed conversion ratio of broiler chicks in the grower and total period of rearing $(p<0.05)$. L-carnitine supplementation significantly increased total protein, globulin, cholesterol, HDL and LDL (high- and low-density lipoprotein) of blood serum in broiler chicks $(p<0.05)$. L-carnitine supplementation increased antibody titer against Newcastle disease of chicks and the highest levels were observed in those with the supplement of L-carnitine in the soybean oil dietary treatment. Results of this experiment showed that the growth performance and blood biochemical responses of broiler chicks to dietary supplementation with L-carnitine in dietary oil source and soybean oil, in comparison to sunflower oil, is the better plant oil for growth and immunological performance of broiler chicks.
\end{abstract}

\section{Introduction}

Plant oils have commonly been used as energy sources in diets of broiler chicks. Advantages of utilizing oils in poultry diet include decrease of feed dust, increase in absorption and hydrolysis of lipoproteins supplying the essential fatty acids, (Nobakht et al., 2011) and improved absorption of vitamin A, vitamin E and Ca (Leeson and Atteh, 1995). However, the chemical structures of fats and oils are extremely variable and therefore the metabolizability and also response of the animal to type of oil may be affected by its source (Sanz et al., 2000). Birds that were fed with diets containing either dietary saturated (beef tallow) or polyunsaturated fat (sunflower oil) showed that the abdominal fat deposition was lowered in chickens receiving the sunflower-oil-enriched diet compared to birds fed with the tallow-enriched diet (Balevi et al., 2000). The most important differences between all kinds of oils and fat sources are related to their fatty acid compositions. The $\mathrm{n}-3$ polyunsaturated fatty acid (n-3 PUFA) content of soybean and sunflower oils is different, the amount of linolenic acid (n-3 PUFA) in sunflower oil is very little, and the ratio of $n-3$ to $n-6$ PUFA of sunflower oil is near zero (Balevi et al., 2000). Oxidation and energy production of various fatty acids are different and related to the number of carbon and double bonds in a carbon chain of fatty acids (unsaturated degree).The major site of fatty acid oxidation in animal cells is the mitochondria and L-carnitine is required for the transfer of long-chain fatty acids from the cytosol to the mitochondrial matrix during lipid catabolism $(\beta$-oxidation); therefore, it plays a vital role in fat combus- 
Table 1. The ingredient and calculated composition of basal diets at starter (1-15 days) and grower (15-35 days) periods.

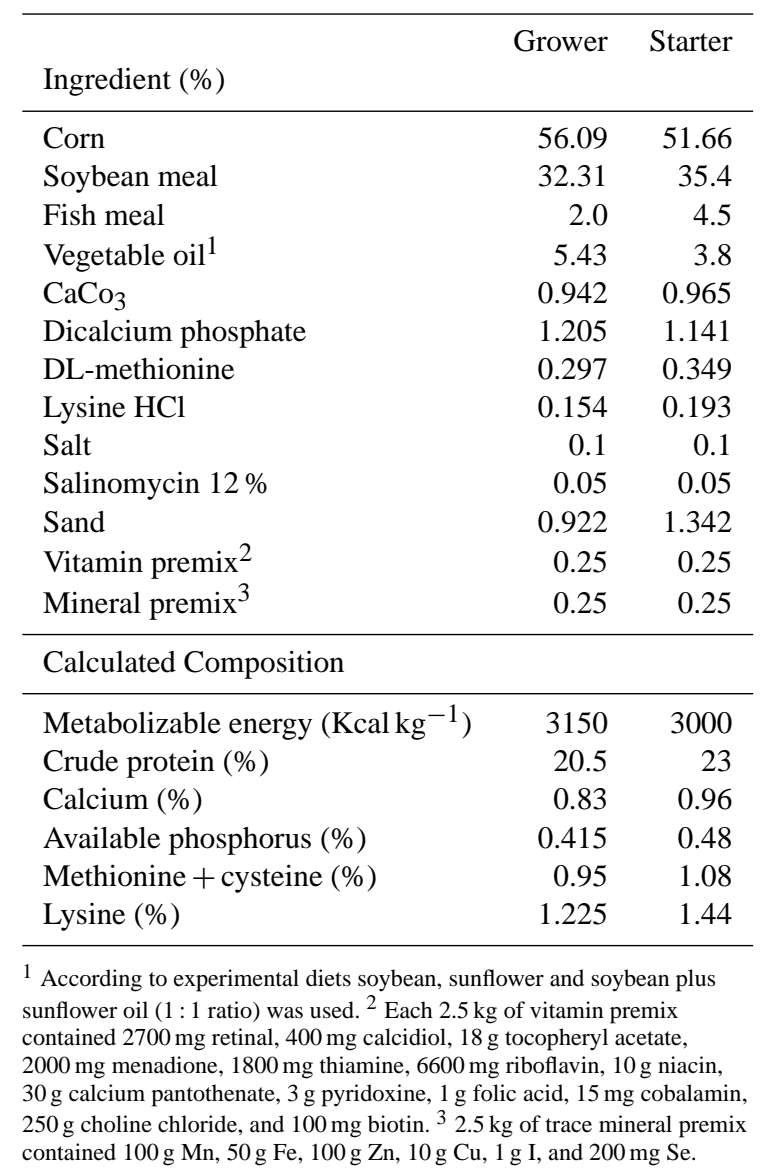

tion (Carter et al., 1995) and energy production (Keralapurath et al., 2010). Alterations in carnitine concentration or metabolism may substantially affect energy production in mitochondria (Arslan, 2006). Theoretically, dietary supplementation of carnitine could be used to facilitate fatty acid oxidation for energy production and improve growth performance of animals. Several studies have been done to study the effect of L-carnitine on broiler chickens, but the results obtained are not in agreement. Some studies have shown that supplemental L-carnitine improved body weight gain and reduced the abdominal fat content of broilers (Rabie et al., 1997a, b) but other research (Xu et al., 2003; Leibetseder, 1995) observed no effects of L-carnitine on chicken growth performance.

Because of the conflicting reports about the effects of Lcarnitine supplementation, it seems that the dietary composition such as oil source (fatty acids) may have an effect on the bird's growth performance. This research has been conducted to study the effects of L-carnitine, soybean and sunflower oil (as different oil source and fatty acid composition) on growth performance, blood biochemical parameters and humoral immune responses of broiler chicks.

\section{Materials and method}

\subsection{Birds and diets}

All procedures used in this experiment were approved by the Department of Animal Science, Faculty of Agriculture, Shahrekord Branch, Islamic Azad University, Shahrekord, Iran. The 240 1-day-old Ross 308 male broiler chicks were weighted individually $(39 \pm 1.2 \mathrm{~g})$ and 10 birds were housed per a cage (24 cages in total) with $1.5 \mathrm{~m} \times 1.5 \mathrm{~m}$ floor space. Birds were maintained under a $23 \mathrm{~h}$ of light in 1 day lighting program and under standard conditions of temperature, humidity and ventilation.

Six dietary treatments were used in this experiment. They were three sources of dietary oil containing soybean, sunflower and soybean plus sunflower oil (1:1 ratio) and two dietary L-carnitine (L-carnitine tartrate, Sigma Tau, Rome, Italy) supplementation levels $\left(0\right.$ and $\left.120 \mathrm{~m} \mathrm{~kg}^{-1}\right)$ in each dietary oil source. Basal starter (1-15 days) and grower (1535 days) diets were formulated based on corn and soybean meal according to the nutrition specifications of Ross 308 broilers (Aviagen, 2014) which contain 3.8 and $5.43 \%$ oil, respectively (Table 1 ). The feed and water were provided ad libitum during the starter and grower periods of the chickens.

\subsection{Data Collection}

Feed consumption and body weight gain of chickens were recorded weekly and the feed conversion ratio (FCR) was calculated as the unit weight of feed per unit of body weight gain at 15 and 35 days of age. There was no mortality during the experimental period.

All chicks were vaccinated against Newcastle disease (B1) by injection of $0.2 \mathrm{~mL}$ per chick at 9 days of age. Also, chicks were orally vaccinated against Newcastle disease (LaSota) at 21 days of age. At 28 days of age, two birds from each replicate of treatments (cages) were randomly selected and blood samples were taken by puncture of the brachial vein for analysis of antibody titers against the Newcastle disease virus (NDV). When the chicks were 35 days of age and after $4 \mathrm{~h}$ of fasting, two chicks were selected randomly from each cage, their weight was measured and blood samples were collected through the brachial vein. Then chicks were then slaughtered by cutting their necks and the liver, heart and abdominal fat pad were immediately removed and weighed. The carcasses ready for cooking (without feathers, head, feet or internal organs) were weighed. The internal organs and carcass were then weighed to derive the relative weight of organs to live body weight.

\subsection{Fatty acid analysis}

For analysis of fatty acid composition and its level of oils, fatty acid methyl esters of oils were prepared according to the method of Christie (1990). Fatty acid methyl esters were separated and quantified by gas chromatography with an Agilent 
model 6890(USA), which is equipped with a flame ionization detector (FID) and a SGE BPX70 capillary column system (BPX-70: $120 \mathrm{~m} \times 0.25 \mathrm{~mm}, 250 \mu \mathrm{m}$ I.D., $0.2 \mu \mathrm{m}$ film thickness, Agilent Technologies). Nitrogen was used as a carrier gas at a $0.9 \mathrm{~mL} \mathrm{~min}^{-1}$ flow rate. The injector and detector temperatures were 260 and $300^{\circ} \mathrm{C}$, respectively. Individual methyl esters were identified in comparison with known mix fatty acid methyl standards and quantified by comparing their peak area with that of the external standard (methyl erucate).

\subsection{Blood analysis}

Serum antibody titers against NDV were measured by the hemagglutination inhibition test (HI), and $\mathrm{HI}$ antibodies were then converted into $\log _{2}$ as described by Landy et al. (2011).

Blood samples were centrifuged ( $3000 \mathrm{~g}$ for $10 \mathrm{~min}$ ) and serum was stored at $-20^{\circ} \mathrm{C}$ until assayed. Concentrations of albumin (ALB), total protein (TP), triglyceride (TG), cholesterol (CHO), High-density lipoprotein (HDL), low-density lipoprotein (LDL) and blood urea nitrogen (BUN) in the serum were measured by an enzymatic method based on ZiestChem Diagnostics kits (Technicon RA1000, Tehran, Iran). Globulin (GLO) was calculated by subtracting the albumin values from the total protein as described by Jalali et al. (2010).

\subsection{Statistical analysis}

The experiment was conducted using a $3 \times 2$ factorial arrangement of treatments (four replicates per treatment) in a completely randomized design with three types of oil source and two levels of L-carnitine as the main effects and the interaction of oil source and L-carnitine supplementation. All data were analyzed using the GLM procedure of SAS software (SAS, 2002) for analysis of variance. When a significant probability value $(P<0.05)$ was detected, significant differences among main effects and interaction of treatment means were determined by Duncan's multiple range tests and least-square means (Lsmeans) of SAS software, respectively.

\section{Results}

Fatty acid compositions of soybean and sunflower oils are presented in Table 2. Soybean oil has the higher saturated and mono-unsaturated fatty acids (oleic acid, C18:1), as well as a lower ratio of unsaturated to saturated fatty acids (3.93) in comparison to sunflower oils.

The effects of soybean oil, sunflower oil and a mix of them plus a supplement of L-carnitine (as main and interaction effect) on body weight gain, feed intake and feed conversion ratio in the starter, grower and total period of chick rearing are presented in Table 3. Daily feed intake of chicks was significantly affected by oil sources $(p<0.05)$ and sunflower oil in the starter period with an increased feed intake, but a mix of sunflower oil and soybean oil reduced it in the grower
Table 2. Fatty acid composition of soybean and sunflower oils.

\begin{tabular}{lrr}
\hline Fatty acids $(\%)$ & Soybean oil & Sunflower oil \\
\hline C14:0 $15: 0$ & 0.21 & 0.16 \\
C15: 1 & 0.03 & - \\
C16:0 $16: 1$ & 0.03 & - \\
C17:0 & 14.85 & 5.24 \\
C17: 1 & 0.17 & 0.08 \\
C18:0 $18: 1$ & 0.11 & 0.05 \\
C18:2 $(\omega-6)$ & 0.07 & 0.04 \\
C20:0 & 4.36 & 4.78 \\
C18:3 $(\omega-3)$ & 25.20 & 16.06 \\
C20: 1 & 47.87 & 70.9 \\
C22:0 & 0.32 & 0.38 \\
C24:0 & 6.21 & 0.39 \\
C24: 1 & 0.19 & 0.19 \\
\hline Saturated & 0.35 & 0.98 \\
Monounsaturated & 0.03 & 0.36 \\
Polyunsaturated & - & 0.39 \\
$\omega 3 / \omega 6$ & 20.26 & 11.95 \\
Unsaturated/saturated & 54.08 & 16.76 \\
\hline
\end{tabular}

period (Table 3). The soybean oil treatment reduced the feed conversion ratio and the lowest was seen in chickens with a feed diet containing soybean oil with L-carnitine supplement in the starter period. In the grower period, the supplementation of L-carnitine to diet containing soybean oil significantly increased feed intake and the highest daily body weight gains were seen with this dietary treatment $(p<0.05)$. On the other hand, the best body weight gain and feed conversion ratio was seen in chicks which were fed with soybean oil with the L-carnitine supplement (Table 3).

The mean body weight at 15 and 35 days of age and the relative internal organ weight of broiler chicks are presented at Table 4. Soybean oil significantly $(p<0.05)$ increased body weight at 35 days of age and the relative weight of the abdominal fat pad, but it reduced the relative weight of the liver and heart in broiler chicks. L-carnitine supplementation increased body weight and the relative weight of the heart and liver. The interaction effect of oil and carnitine showed that addition of L-carnitine to a soybean oil diet improved body weight and increased the relative weight of the liver in chicks. Addition of L-carnitine to a diet which containing sunflower oil reduced relative weight of the abdominal fat pad (Table 4).

Table 5 shows the effects of oil sources and L-carnitine on some blood biochemical parameters and antibody titer against NDV of broiler chicks. L-carnitine supplementation significantly $(P<0.05)$ increased the level of total protein, globulin, cholesterol, HDL and LDL, and reduced triglycerides in the blood serum of broiler chicks. The serum level 
Table 3. Effects of dietary oil sources and L-carnitine supplementation on growth performance of broiler chicks in the starter, grower and total period of rearing.

\begin{tabular}{|c|c|c|c|c|c|c|c|c|c|}
\hline \multirow[b]{2}{*}{ Treatment } & \multicolumn{3}{|c|}{ Starter period (1-15 days) } & \multicolumn{3}{|c|}{ Grower period (16-35 days) } & \multicolumn{3}{|c|}{ Total period (1-35 days) } \\
\hline & $\begin{array}{l}\mathrm{DFI}^{1} \\
\left(\mathrm{~g} \mathrm{bird}^{-1}\right)\end{array}$ & $\begin{array}{l}\mathrm{DBWG}^{2} \\
\left(\mathrm{~g} \mathrm{bird}^{-1}\right)\end{array}$ & $\mathrm{FCR}^{3}$ & $\begin{array}{l}\mathrm{DFI}^{1} \\
\left(\mathrm{~g} \mathrm{bird}^{-1}\right)\end{array}$ & $\begin{array}{l}\mathrm{DBWG}^{2} \\
\left(\mathrm{~g} \mathrm{bird}^{-1}\right)\end{array}$ & $\mathrm{FCR}^{3}$ & $\begin{array}{l}\mathrm{DFI}^{1} \\
\left(\mathrm{~g} \mathrm{bird}^{-1}\right)\end{array}$ & $\begin{array}{l}\mathrm{DBWG}^{2} \\
\left(\mathrm{~g} \mathrm{bird}^{-1}\right)\end{array}$ & $\mathrm{FCR}^{3}$ \\
\hline \multicolumn{10}{|l|}{ Main effect } \\
\hline \multicolumn{10}{|l|}{ Oil source } \\
\hline Sunflower & $46.47^{\mathrm{a}}$ & 34.98 & $1.32^{\mathrm{a}}$ & $141.38^{\mathrm{a}}$ & $66.17^{\mathrm{a}}$ & $2.15^{\mathrm{b}}$ & 120.04 & $57.8^{\mathrm{ab}}$ & $2.09^{\mathrm{a}}$ \\
\hline Sunflower \& soybean & $42.59^{\mathrm{b}}$ & 33.73 & $1.26^{\mathrm{ab}}$ & $135.56^{\mathrm{b}}$ & $59.39^{\mathrm{b}}$ & $2.28^{\mathrm{a}}$ & 115.67 & $55.06^{\mathrm{b}}$ & $2.10^{\mathrm{a}}$ \\
\hline Soybean & $42.00^{\mathrm{b}}$ & 34.36 & $1.22^{\mathrm{b}}$ & $146.80^{\mathrm{a}}$ & $67.76^{\mathrm{a}}$ & $2.18^{\mathrm{ab}}$ & 120.72 & $61.67^{\mathrm{a}}$ & $1.96^{\mathrm{b}}$ \\
\hline \multicolumn{10}{|l|}{ L-carnitine level $\left(\mathrm{mg} \mathrm{kg}^{-1}\right)$} \\
\hline 0 & $42.17^{\mathrm{b}}$ & 33.73 & 1.25 & 139.79 & 63.78 & 2.19 & 117.45 & 58.11 & 2.02 \\
\hline 120 & $45.10^{\mathrm{a}}$ & 34.98 & 1.28 & 143.00 & 65.10 & 2.21 & 120.17 & 58.29 & 2.08 \\
\hline \multicolumn{10}{|l|}{ Interaction effect } \\
\hline Sunflower oil & $43.45^{\mathrm{b}}$ & 4.27 & $1.27^{\mathrm{abc}}$ & $143.17^{\mathrm{b}}$ & $6879^{\mathrm{ab}}$ & $2.08^{\mathrm{cd}}$ & $120.29^{\mathrm{ab}}$ & $62.2^{\mathrm{ab}}$ & $1.93^{\mathrm{bc}}$ \\
\hline Sunflower \& soybean oil & $41.59^{\mathrm{b}}$ & 33.59 & $1.23^{\mathrm{bc}}$ & $135.92^{\mathrm{b}}$ & $62.00^{\mathrm{bc}}$ & $2.19^{\mathrm{bc}}$ & $114.52^{\mathrm{b}}$ & $55.5^{\mathrm{ab}}$ & $2.06^{\mathrm{ab}}$ \\
\hline Soybean oil & $41.48^{\mathrm{b}}$ & 33.35 & $1.24^{\mathrm{abc}}$ & $140.28^{\mathrm{b}}$ & $60.54^{\mathrm{c}}$ & $2.31^{\mathrm{ab}}$ & $117.54^{\mathrm{ab}}$ & $56.5^{\mathrm{bc}}$ & $2.08^{\mathrm{ab}}$ \\
\hline Sunflower oil \& L-carnitine & $49.15^{\mathrm{a}}$ & 35.69 & $1.38^{\mathrm{a}}$ & $140.49^{\mathrm{b}}$ & $63.54^{\mathrm{bc}}$ & $2.21^{\mathrm{bc}}$ & $119.78^{\mathrm{ab}}$ & $53.42^{\mathrm{c}}$ & $2.24^{\mathrm{a}}$ \\
\hline Sunflower, soybean oil \& L-carnitine & $43.59^{\mathrm{b}}$ & 33.88 & $1.29^{\mathrm{ab}}$ & $135.20^{\mathrm{b}}$ & $56.78^{\mathrm{c}}$ & $2.38^{\mathrm{a}}$ & $116.83^{\mathrm{ab}}$ & $54.50^{\mathrm{ab}}$ & $2.14^{\mathrm{a}}$ \\
\hline Soybean oil \& L-carnitine & $42.56^{\mathrm{b}}$ & 35.38 & $1.20^{\mathrm{c}}$ & $153.31^{\mathrm{a}}$ & $74.98^{\mathrm{a}}$ & $2.04^{4}$ & $123.90^{\mathrm{a}}$ & $66.83^{\mathrm{a}}$ & $1.85^{\mathrm{b}}$ \\
\hline PSEM $^{4}$ & 0.923 & 0.828 & 0.03 & 2.615 & 2.303 & 0.048 & 2.323 & 1.994 & 0.054 \\
\hline
\end{tabular}

Table 4. Effects of dietary oil sources and L-carnitine supplementation on mean body weight (15 and 35 days old) and relative weight of the internal organs to the live bodies ( 35 days) of broiler chicks.

\begin{tabular}{|c|c|c|c|c|c|c|}
\hline Treatment & $\begin{array}{r}\text { Body weight } \\
(15 \text { days, g) }\end{array}$ & $\begin{array}{l}\text { Body weight } \\
\text { (35 days, g) }\end{array}$ & $\begin{array}{l}\text { Rel. Heart }{ }^{1} \\
(\%)\end{array}$ & $\begin{array}{l}\text { Rel. Liver }{ }^{1} \\
(\%)\end{array}$ & $\begin{array}{l}\text { Rel. Spleen } 1 \\
(\%)\end{array}$ & $\begin{array}{l}\text { Rel. Fat pad }{ }^{1} \\
(\%)\end{array}$ \\
\hline \multicolumn{7}{|l|}{ Main effect } \\
\hline \multicolumn{7}{|l|}{ OIL } \\
\hline Sunflower & 564.9 & $2401.2^{\mathrm{b}}$ & $0.66^{\mathrm{a}}$ & $2.23^{\mathrm{bc}}$ & 0.144 & $2.01^{\mathrm{b}}$ \\
\hline Sunflower \& soybean & 556.2 & $2240.0^{\mathrm{c}}$ & $0.65^{\mathrm{a}}$ & $2.42^{\mathrm{a}}$ & 0.111 & $1.89^{\mathrm{b}}$ \\
\hline Soybean & 563.8 & $2493.7^{\mathrm{a}}$ & $0.60^{\mathrm{b}}$ & $2.11^{b}$ & 0.113 & $2.58^{\mathrm{a}}$ \\
\hline \multicolumn{7}{|l|}{ L-carnitine level $\left(\mathrm{mg} \mathrm{kg}^{-1}\right)$} \\
\hline 0 & 556.30 & $2337.0^{\mathrm{b}}$ & $0.59^{\mathrm{b}}$ & $2.10^{\mathrm{b}}$ & 0.128 & 2.20 \\
\hline 120 & 567.1 & $2419.6^{\mathrm{a}}$ & $0.68^{\mathrm{a}}$ & $2.41^{\mathrm{a}}$ & 0.116 & 2.12 \\
\hline \multicolumn{7}{|l|}{ Interaction effect } \\
\hline Sunflower oil & 562.7 & $2493.9^{b}$ & $0.62^{\mathrm{ab}}$ & $2.21^{\mathrm{ab}}$ & $0.163^{\mathrm{a}}$ & $2.27^{\mathrm{bc}}$ \\
\hline Sunflower \& soybean oil & 554.5 & $2223.1^{\mathrm{c}}$ & $0.61^{\mathrm{ab}}$ & $2.29^{\mathrm{a}}$ & $0.079^{\mathrm{b}}$ & $1.60^{\mathrm{cd}}$ \\
\hline Soybean oil & 551.7 & $2294.0^{\mathrm{c}}$ & $0.56^{\mathrm{b}}$ & $1.82^{\mathrm{b}}$ & $0.127^{\mathrm{ab}}$ & $2.38^{\mathrm{b}}$ \\
\hline Sunflower oil \& L-carnitine & 567.2 & $2308.5^{c}$ & $0.70^{\mathrm{a}}$ & $2.26^{\mathrm{a}}$ & $0.116^{\mathrm{ab}}$ & $1.75^{\mathrm{d}}$ \\
\hline Sunflower, soybean oil \& L-carnitine & 558.0 & $2256.9^{c}$ & $0.70^{\mathrm{a}}$ & $2.56^{\mathrm{a}}$ & $0.134^{\mathrm{ab}}$ & $1.82^{\mathrm{d}}$ \\
\hline Soybean oil \& L-carnitine & 576.0 & $2693.4^{\mathrm{a}}$ & $0.64^{\mathrm{ab}}$ & $2.41^{\mathrm{a}}$ & $0.099^{\mathrm{ab}}$ & $2.78^{\mathrm{a}}$ \\
\hline PSEM $^{2}$ & 11.15 & 39.56 & 0.02 & 0.13 & 0.018 & 0.11 \\
\hline
\end{tabular}

${ }^{1}$ Rel.: relative weight of organs to live body weight at 35 days of age; ${ }^{2}$ PSEM: pooled standard error of mean. ${ }^{\text {a-c }}$ Column values with the same superscripts or no superscript are not significantly different $(P>0.05)$. 
Table 5. Effects of soybean, sunflower oil and L-carnitine supplementation on some blood biochemical parameters of broiler chicks.

\begin{tabular}{|c|c|c|c|c|c|c|c|c|c|}
\hline Treatment & $\begin{array}{l}\mathrm{ALB}^{1} \\
\left(\mathrm{~g} \mathrm{dl}^{-1}\right)\end{array}$ & $\begin{array}{l}\mathrm{TP}^{1} \\
\left(\mathrm{~g} \mathrm{dl}^{-1}\right)\end{array}$ & $\begin{array}{l}\mathrm{GLO}^{1} \\
\left(\mathrm{~g} \mathrm{dl}^{-1}\right)\end{array}$ & $\begin{array}{l}\mathrm{CHO}^{1} \\
\left(\mathrm{mg} \mathrm{dl}^{-1}\right)\end{array}$ & $\begin{array}{l}\mathrm{TG}^{1} \\
\left(\mathrm{mg} \mathrm{dl}^{-1}\right)\end{array}$ & $\begin{array}{l}\mathrm{HDL}^{1} \\
\left(\mathrm{mg} \mathrm{dl}^{-1}\right)\end{array}$ & $\begin{array}{l}\mathrm{LDL}^{1} \\
\left(\mathrm{mg} \mathrm{dl}^{-1}\right)\end{array}$ & $\begin{array}{l}\mathrm{BUN}^{1} \\
\left(\mathrm{mg} \mathrm{dl}^{-1}\right)\end{array}$ & $\begin{array}{l}\text { AT. NDV } 2 \\
\left(\log _{2}\right)\end{array}$ \\
\hline \multicolumn{10}{|l|}{ Main effect } \\
\hline \multicolumn{10}{|l|}{ OIL } \\
\hline Sunflower & 2.12 & 3.88 & 1.88 & $182.83^{\mathrm{b}}$ & $91.83^{\mathrm{a}}$ & $96.5^{\mathrm{b}}$ & $70.16^{\mathrm{b}}$ & $2.08^{\mathrm{b}}$ & $3.5^{\mathrm{a}}$ \\
\hline Sunflower\& soybean & 2.16 & 3.95 & 1.93 & $251.50^{\mathrm{a}}$ & $76.00^{\mathrm{b}}$ & $111.66^{\mathrm{a}}$ & $117.66^{\mathrm{a}}$ & $3.59^{\mathrm{a}}$ & $3.05^{\mathrm{b}}$ \\
\hline Soybean & 2.10 & 3.75 & 1.81 & $186.50^{\mathrm{b}}$ & $91.83^{\mathrm{a}}$ & $103.66^{\mathrm{b}}$ & $62.50^{\mathrm{b}}$ & $1.62^{\mathrm{c}}$ & $3.42^{\mathrm{ab}}$ \\
\hline \multicolumn{10}{|l|}{ L-carnitine $\left(\mathrm{mg} \mathrm{kg}^{-1}\right)$} \\
\hline 0 & 1.93 & $3.52^{\mathrm{b}}$ & $1.70^{\mathrm{b}}$ & $187.22^{\mathrm{b}}$ & $98.55^{\mathrm{a}}$ & $97.33^{\mathrm{a}}$ & $73.11^{b}$ & 2.27 & $3.12^{\mathrm{b}}$ \\
\hline 120 & 1.96 & $4.20^{\mathrm{a}}$ & $2.05^{\mathrm{a}}$ & $226.67^{\mathrm{a}}$ & $74.55^{\mathrm{b}}$ & $110.55^{\mathrm{b}}$ & $93.77^{\mathrm{a}}$ & 2.59 & $3.53^{\mathrm{a}}$ \\
\hline \multicolumn{10}{|l|}{ Interaction effect } \\
\hline Sunflower oil & 2.23 & 3.71 & $2.03^{b}$ & $168.00^{\mathrm{b}}$ & $71.00^{\mathrm{b}}$ & $101.33^{\mathrm{b}}$ & $65.00^{\mathrm{cd}}$ & $2.3^{\mathrm{c}}$ & $3.30^{\mathrm{ab}}$ \\
\hline Sunflower \& soybean oil & 2.3 & 3.59 & $1.30^{\mathrm{c}}$ & $211.33^{\mathrm{b}}$ & $78.66^{\mathrm{b}}$ & $87.00^{\mathrm{c}}$ & $90.33^{\mathrm{b}}$ & $3.12^{\mathrm{b}}$ & $3.33^{\mathrm{ab}}$ \\
\hline Soybean oil & 2.12 & 3.39 & $1.76^{\mathrm{b}}$ & $182.33^{\mathrm{b}}$ & $74.00^{\mathrm{b}}$ & $103.66^{\mathrm{b}}$ & $64.00^{\mathrm{cd}}$ & $1.40^{\mathrm{d}}$ & $2.75^{\mathrm{b}}$ \\
\hline Sunflower oil \& L-carnitine & 2.33 & 4.06 & $1.73^{\mathrm{b}}$ & $197.67^{\mathrm{b}}$ & $112.66^{\mathrm{a}}$ & $91.66^{\mathrm{bc}}$ & $75.33^{\mathrm{c}}$ & $1.87^{\mathrm{cd}}$ & $3.7^{\mathrm{ab}}$ \\
\hline Sunflower, soybean oil \& L-carnitine & 2.08 & 4.12 & $2.56^{\mathrm{a}}$ & $291.67^{\mathrm{a}}$ & $73.33^{\mathrm{b}}$ & $136.33^{\mathrm{a}}$ & $145.00^{\mathrm{a}}$ & $4.06^{\mathrm{a}}$ & $2.79^{\mathrm{b}}$ \\
\hline Soybean oil \& L-carnitine & 2.36 & 4.13 & $1.86^{\mathrm{b}}$ & $190.67^{\mathrm{b}}$ & $109.66^{\mathrm{a}}$ & $103.66^{\mathrm{b}}$ & $61.00^{\mathrm{d}}$ & $1.84^{\mathrm{cd}}$ & $4.10^{\mathrm{a}}$ \\
\hline PSEM $^{3}$ & 0.18 & 0.29 & 0.12 & 15.02 & 5.25 & 3.64 & 4.35 & 0.19 & 0.21 \\
\hline
\end{tabular}

of triglycerides, cholesterol, HDL, LDL and BUN were significantly $(P<0.05)$ affected by the dietary oil source and the mix of soybean and sunflower oil increased cholesterol, HDL, LDL and BUN and reduced triglyceride concentration of blood sera. The interaction effect of L-carnitine with oil sources showed that addition of L-carnitine to a diet which contains a mix of soybean and sunflower oil increased the serum level of globulin, cholesterol, HDL, LDL and BUN of chicks (Table 5).

\section{Discussion}

The fatty acid composition is an important criterion to evaluating the use of fat in the intensive feeding of poultry (Burlikowska et al., 2010). Sunflower oil has the higher percentage of linoleic acid (C18:2, $\omega-6)$, as omega 6 fatty acids and therefore this plant oil has the lower $\omega-3$ to $\omega-6$ fatty acid ratio in comparison to soybean oils (Table 2).

The highest amount of feed intake by adding sunflower oil into the diets of broiler chicks in the starter period may be related to the low density of metabolizable and digestible energy in this oil in comparison to soybean oil (Alao and Balnave, 1984; Leeson and Summers, 2001) in the starter period. This result is in agreement with Nobakht et al. (2011), who report that feed intake increased by addition of sunflower oil at $4 \%$ in the starter diet of broiler chicks. Addition of L-carnitine supplementation to diets which contained sunflower oil increased the feed intake of chicks in the starter period and this is in agreement with the report of
Sayed et al. (2001), which e demonstrated that addition of L-carnitine $(50 \mathrm{ppm})$ to a diet containing 2 and $4 \%$ of sunflower oil increased feed intake. Corduk and Sarica (2008) also showed that L-carnitine addition (500 ppm) to a diet containing sunflower oil increased the feed intake of laying hen. In contrast to the abovementioned research, Zhang et al, 2010 showed a reduced daily feed intake of male broilers by supplementing with different dietary levels of L-carnitine (300, 600 and 900 ppm) a diet which contained corn oil. Nevertheless, Manoochehri Ardekani et al. (2012) also reported that L-carnitine supplementation at $50 \mathrm{ppm}$ levels to a diet which contained soybean oil reduced the feed intake of broiler chicks. The main effects showed that soybean oil improved the feed conversion ratio of chicks in the total period (Table 3). This may be due to the optimum ratio of unsaturated to saturated fatty acids of soybean oil. The important factor affecting the amount of fat metabolizable energy is their digestibility, and it is dependent on the age of birds, the length of carbon chain and the degree of saturation of fatty acids (Leeson and Summers, 1997). Moreover, Leeson and Summers (1997) reported that the optimum ratio of unsaturated to saturated fatty acids for maximizing fat digestibility and the metabolizable energy value of fat is around 3 to 1 . Also, oleic acid (C18:1), of which soybean oil has a higher content compared to other dietary oils (Table 3), plays a direct role in the absorption of saturated fatty acids in the lumen and mucosa cells and facilitated their absorption (Young and Garrett, 1963). On the other hand, Batal and Parsons (2002) showed that the metabolizable energy of a corn-soy diet supplemented with soybean oil was maximized in broiler chicks. 
Therefore, soybean oil have a higher digestibility and metabolizable energy which improved the body weight gain and feed conversion ratio of chicks.

Dietary L-carnitine supplementation alone had no effect on growth performance of broiler chicks, except for feed intake in the starter period which increased with the Lcarnitine supplement (Table 3). This finding is in agreement with other research (Curdak et al., 2007; Lien and Horng, 2001; Xu et al., 2003; Kheiri et al., 2011) which reports that L-carnitine supplementation did not have an effect on the growth performance of broiler chicks. Nevertheless, the results of Parsaeimehr et al. (2012) showed that using Lcarnitine $(300 \mathrm{ppm})$ in diets which contained $5 \%$ animal fat improved body weight gain and feed conversion ratio of broiler chicks in a comparison to diets containing $5 \%$ soybean oil. Xu et al. (2003) reported that supplementation of L-carnitine at $0,25,50,75$ and $100 \mathrm{ppm}$ of diet, which contained $5 \%$ corn oil, had no effect on growth performance of male broiler chicks. In the present study, growth performance of chicks improved by using L-carnitine when the diet contained soybean oil (Table 3), and this may be related to improved oxidation of fatty acids in soybean oil by the L-carnitine supplement. Therefore, the growth response of birds to L-carnitine supplementation was affected by the dietary oil source. According to recent results, the response of chicks and quail to the L-carnitine supplement may be related to dietary composition such as the amino acid level, especially methionine and lysine (Sadeghzadeh et al., 2014; precursors of endogenous biosynthesis of L-carnitine), and type of dietary oil source.

Dietary treatments have some effect on the weight of internal organs such as the liver and heart (Table 4). Nevertheless, the results of Nobakht et al. (2011) showed that sunflower, soybean, and canola oils and their combination with a chick's diet had no effect on the relative weight of the bird's liver. Also, Lien and Horng (2001) showed that supplementation with $160 \mathrm{ppm}$ of L-carnitine in a broiler diet had no effect on liver weight. The results of Rabie and Szilagyi (1998) showed that the relative weight of the liver, gizzard and heart of chicks were not affected by feeding them $50 \mathrm{ppm}$ of L-carnitine. On the other hand, results of Buyse et al. (2001) showed that $100 \mathrm{ppm}$ of L-carnitine increased the heart's weight in chicks, and they also mentioned that increased heart weight is likely to be part of a cardiovascular adaptive mechanism to meet greater oxygen needs for thermoregulatory purposes. Reported that the dietary fat source may affect the metabolism and deposition of fat in broiler chickens and that feeding sunflower oil reduced the abdominal fat deposition in chickens (Pesti et al., 2002; Sanz et al., 2000). Sanz et al. (2000) suggested that the lower fat deposition in broilers fed with sunflower-oil-enriched diets resulted from the increase of lipid catabolism and the decrease of fatty acid synthesis despite higher dietary fat absorption.

Theoretically, supplementing the broiler diet with carnitine would facilitate the fatty acid oxidation and decrease es- terification reactions and triacylglycerol storage in the adipose tissue. Postprandial plasma triglyceride concentrations were reduced too, showing that the dietary lipid clearance from the bloodstream to tissues was amplified. L-carnitine may increase fatty acid oxidation and thus reduce blood triglycerides levels in chicks. On the other hand, the results of Parizadian et al. (2011) indicated that the quails were fed with rations containing L-carnitine supplementation and, in comparison with the control group, had less triglycerides in the blood.

Addition of L-carnitine to diets increased its concentration in muscles and liver and caused leads to increase the activity of carnitine acetyltransferase and accelerate the transport of acetyl-CoA (coenzyme A) from the mitochondria to the cytosol. Acetyl-CoA is the source of all the carbon atoms in cholesterol; on the other hand, Bouyeh (2012) reported that the higher dietary level of lysine and methionine (two precursors of L-carnitine) in comparison to the National Research Council for poultry (1994) level increase cholesterol, LDL and HDL in the serum of broiler chicks. The increasing serum protein (albumin or globulin) with the dietary Lcarnitine supplement reported previously may be related to its protein sparing action (Jalali et al., 2010) and reduced using the amino acid precursor (lysine and methionine) for L-carnitine biosynthesis. The concentration of BUN in the serum of chicks was altered by dietary treatments and soybean oil reduced it (Table 5). This reduction may be due to improving the use amino acids for growth of broiler chicks. Addition of L-carnitine to mixed oil treatments increased the serum level of BUN and this response may be due to higher amino acid availability for catabolism. On the other hand, results of Yang et al. (2009) also showed that higher protein levels in diets of broiler chicks increased the serum level of BUN.

Supplementing the diets of broiler chicks with L-carnitine improved the antibody titer against NDV in the serum. On the other hand, addition of L-carnitine to diets which contain only soybean oil increased antibody titer against NDV (Table 5). Results of Friedman and Sklan (1997) showed that antibody titer against NDV for turkey increased at a dietary ratio of n-3 to n- 6 fatty acids of nearly 0.13 and this ratio is comparable to the fatty acid composition of soybean oil (Table 2). Moreover, Pilevar et al. (2011) also reported that a dietary ratio of n- 6 to $n-3$ fatty acids at 10 levels increased antibody titer against NDV in pullet chicks, and this ratio in soybean oil was 7.8 (Table 2). Previously reported that feeding broiler chickens by a lysine-deficient diet (lysine is a precursor of L-carnitine biosynthesis) reduced antibody response to NDV vaccination (Chen et al., 2003). On the other hand, carnitine could be effective on the immune system because it has been found to exhibit immunomodulatory effects during in vivo experiments (Kurth et al. 1994).

Overall, the results of this experiment showed that soybean oil, in comparison to sunflower oil, is the better plant oil for the growth and immunological performance of broiler 
chicks and its response to the dietary L-carnitine supplement related to plant oil sources.

Edited by: S. Maak

Reviewed by: two anonymous referees

\section{References}

Alao, S. J. and Balnave, D.: Growth and carcass composition of broiler fed sunflower and olive oil, Brit. Poult. Sci., 25, 209-219, 1984.

Arslan, C.: L-Carnitine and its use as a feed additive in poultry feeding a review, Rev. Med. Vet., 157, 134-142, 2006.

Balevi, T. and Coskun, B.: Effects of some dietary oils on performance and fatty acid composition of eggs in layers, Rev. Med. Vet., 151, 847-854, 2000.

Batal, A. B. and Parsons, C. M.: Effects of age on nutrient digestibility in chicks fed different diets, Poult. Sci., 81, 400-407, 2002.

Bouyeh, M.: Effect of excess lysine and methionine on immune system and performance of broilers, Ann. Biol. Res., 3, 3218-3224, 2012.

Burlikowska, K., Piotrowska A., and Szymeczko R.: Effect of dietary fat type on performance, biochemical indices and fatty acids profile in the blood serum of broiler chickens, J. Anim. Feed Sci., 19, 440-451, 2010.

Buyse, J., Janssens, G. P. J., and Decuypere, E.: The effects of dietary L-carnitine supplementation on the performance, organ weights and circulating hormone and metabolite concentrations of broiler chickens reared under a normal or low temperature schedule, Brit. Poult. Sci., 42, 230-241, 2001.

Carter, A. L., Abney, T. O., and Lapp, D. F.: Biosynthesis and metabolism of carnitine, J. Child. Neurol., 10, 3-7, 1995.

Chen, C., Sander, J. E., and Dale, N. M.: The effect of dietary lysine deficiency on the immune response to Newcastle disease vaccination in chickens, Avian Dis., 47, 1346-1351, 2003.

Christie, W. W. (Ed.): The analysis of fatty acids, preparation of methyl ester and other derivatives, in: Gas Chromatography and Lipids - A Practical Guide, Oily Press, Bridgwater, UK, 36-47, 1990.

Corduk, M., Ceylan, N., and Ildiz, F.: Effects of dietary energy density and L-carnitine supplementation on growth performance, carcass traits and blood parameters of broiler chickens, S. Afr. J. Anim. Sci., 37, 65-73, 2007.

Corduk, M. and Sarica, S.: Effects of L-carnitine in layer diets containing different fat sources and energy levels on hen performance and egg quality, S. Afr. J. Anim. Sci., 38, 260-270, 2008.

Friedman, A. and Sklan, D.: Effect of dietary fatty acids on humoral immune response in turkeys, Brit. Poult. Sci., 38, 342-348, 1997.

Jalali-Haji Abadi, S. M. A., Mahboobi-Soofiani, N., Sadeghi, A. A., Chamani, M., and Riazi, G.: Effects of supplemental dietary Lcarnitine and ractopamine on the performance of juvenile rainbow trout (Oncorhynchus mykiss), Aqua. Res., 41, 1582-1591, 2010.

Keralapurath, M. M., Keirs, R. W., Corzo, A., Bennett, L. W., Pulikanti, R., and Peebles, E. D.: Effects of in ovo injection of L-carnitine on subsequent broiler chick tissue nutrient profiles, Poult. Sci., 89, 335-341, 2010.

Kheiri, F., Pourreza, J., Ebrahimnezhad, Y., and Jalali-Haji Abadi, S. M. A.: Effect of supplemental ractopamine and L-carnitine on growth performance, blood biochemical parameters and carcass traits of male broiler chicks, Afr. J. Biotech., 68, 15450-15455, 2011.

Kurth, L., Fraker, P., and Bieber, L.: Utilization of intracellular acylcarnitine pools by mononuclear phagocytes, Biochim. Biophys. Acta, 11, 321-327, 1994.

Landy, N., Ghalamkari Gh., and Toghyani, M.: Performance, carcass characteristics, and immunity in broiler chickens fed dietary neem (Azadirachta indica) as alternative for an antibiotic growth promoter, Livest Sci., 142, 305-309, 2011.

Leeson, S. and Atteh, J. O.: Utilization of fats and fatty acids by turkey poults, Poult. Sci., 74, 2003-2010, 1995.

Leeson, S. and Summers, J. D.: Commercial Poultry Nutrition, 2nd Edn. University of Books, Guelph, ON, Canada, 355 pp., 1997.

Leeson, S. and Summers, J. D.: Nutrition of the Chicken, 4th Edn. University of Books, Ontario, Canada, 591 pp., 2001.

Leibetseder, J.: Studies on the effects of L-carnitine in poultry, Arch. Anim. Nutr., 48, 97-108, 1995.

Lien, T. F. and Horng, Y. M.: The effect of supplementary dietary Lcarnitine on the growth performance, serum components, carcass traits and enzyme activities in relation to fatty acid $\beta$-oxidation of broiler chickens, Brit. Poult. Sci., 42, 92-95, 2001.

Manoochehri Ardekani, H., Shevazad, M., Chamani, M., Aminafshar, M., and Darsi Arani, M.: The effect of L-carnitine and low crude protein supplemented with crystalline essential amino acids diets on broiler chickens, Ann. Biol. Res., 3, 1085-1093, 2012.

Mossab, A., Hallouis, J. M., and Lessire, M.: Utilization of soybean oil and tallow in young turkeys compared with young chickens, Poult. Sci., 79, 1326-1331, 2000.

Nobakht, A., Tabatbaei, S., and Khodaei, S.: Effects of different sources and levels of vegetable oils on performance, carcass traits and accumulation of vitamine in breast meat of broilers, Curr. Res. J. Biol. Sci, 3, 601-605, 2011.

Parizadian, B., Shams Shargh, M., and Zerehdaran, S.: Study the effects of different levels of energy and L-carnitine on meat quality and serum lipids of Japanese quail, Asian. J. Anim. Vet. Advances, 6, 944-952, 2011.

Parsaeimehr, K., Farhoomand, P., and Najafi, R.: The effects of Lcarnitine with animal fat on performance, carcass characteristics and some blood parameters of broiler chickens, Ann. Biol. Res., 3, 3663-3666, 2012.

Pesti, G. N., Bakalli, R. I., Qiao, M., and Sterling K. G.: A comparison of eight grades of fats as broiler feed ingredients. Poult. Sci., 81, 382-390, 2002.

Pilevar, M., Arshami, J., Golian, A., and Basami, M. R.: Effects of dietary n-6:n-3 ratio on immune and reproductive systems of pullet chicks, Poult. Sci., 90, 1758-1766, 2011.

Rabie, M. H., Szilagyi, M., and Gippert, T.: Effects of dietary Lcarnitine supplementation and protein level on performance and degree of meatiness and fatness of broilers, Acta. Biol. Hung., 48, 221-239, 1997a.

Rabie, M. H., Szilagyi, M., Gippert, T., Votisky, E., and Gerendai, D.: Influence of dietary L-carnitine on performance and carcass quality of broiler chickens, Acta. Biol. Hung., 48, 241-252, $1997 b$.

Rabie, M. H. and Szilagyi, M.: Effects of L-carnitine supplementation of diets differing in energy levels on performance, abdominal 
fat content and yield and composition of edible meat of broilers, Brit. J. Nutr., 80, 391-400, 1998.

Sadeghzadeh, S. S., Yazdian, M. R., and Nasr, J.: The effects of different levels of L-Carnitine and methionine on performance and blood metabolites in female broiler, Res. Opin. Anim. Vet. Sci., 4, 427-431, 2014.

Sanz, M., Lopez-Bote, C. J., Menoyo, D., and Bautista, J. M.: Abdominal fat deposition and fatty acid synthesis are lower and Boxidation is higher in broiler chickens fed diets containing unsaturated rather than saturated fat, J. Nutr., 130, 3034-3037, 2000.

Sayed, A. N., Shoeib, H. K., and Abdel-Raheem, H. A.: Effect of dietary L-carnitine on the performance of broiler chickens fed on different levels of fat, Assiut Vet. Med. J., 45, 37-47, 2001.

SAS: Statistical Analysis System, Institute Inc. SAS/STAT User's Guide, Version 9.1, SAS Institute Inc., Cary, NC, USA, 2002.

Xu, Z. R., Wang, M. Q., Mao, H. X., Zhan, X. A., and Hu, C. H.: Effects of L-carnitine on growth performance, carcass composition, and metabolism of lipids in male broilers, Poult. Sci., 82, 408-413, 2003.
Yang, Y. X., Guo, J., Yoon, S. Y., Jin, Z., Choi, J. Y., Piao, X. S., Kim, B. W., Ohh, S. J., Wang, M. H., and Chae, B. J.: Early energy and protein reduction: effects on growth, blood profiles and expression of genes related to protein and fat metabolism in broilers, Brit. Poult. Sci., 50, 218-227, 2009.

Young, R. J. and Garrett, R. L.: Effect of oleic and linoleic acids on the absorption of saturated fatty acids in the chick, J. Nutr., 81, 321-329, 1963.

Zhang, Y., Ma, Q., Bai, X., Zhao, L., Wang, Q., Ji, C., Liu, L., and Yin, H.: Effects of dietary acetyl-L-carnitine on meat quality and lipid metabolism in arbor acres broilers, Asian-Aust, J. Anim. Sci., 23, 1639-1644, 2010. 